\title{
Review of Hussain Sagar Lake Pollution, Hyderabad, India
}

\author{
P. Mahammed Rafi ${ }^{1}$, Acharya Jyothi Kusum ${ }^{2}$ \\ ${ }^{1}$ Asst. Professor, Mallareddy Institute of Technology and Sciences, Hyderabad, India \\ ${ }^{2}$ Associate Professor, Mallareddy Institute of Technology and Sciences, Hyderabad, India
}

\begin{abstract}
Hussain sagar lake, a historical lake which was built in 1562 by Hussain Shaw Wali is situated in the heart of Hyderabad city, India. Earlier up to 1930's, it was the major water source to meet drinking and irrigation requirements for both twin cities of Hyderabad and Secunderabad. Now this lake turned to virtual garbage bin with no adequate treatment for wastewater loads originated from point and non point sources. Therefore the lake loses the capability of self purification system which was an important factor that depends on the maximum uptake of oxygen from the atmosphere. Multiple projects were undertaken by the concerned authorities for the improvement of Hussain sagar lake and its catchment area. Recently With referring to the Lake health status, In 2006, HMDA, a governing body set up by Andhra Pradesh Government, initiated "Hussainsagar Lake and Catchment Area Improvement project" and set up STPS and wastewater interception and diversion structures. It also installed fountains to aerate the lake to improve its water quality as well as to add beauty. But these measures are lying ineffective to manage wastewater loads.

This paper discusses that the Hussain Sagar lake water body over decades, has been polluted adversely from discharging of organic and inorganic pollutants through open drains as well as point and non point sources and also presents various measures had taken to rejuvenate Hussain Sagar Lake to its past glory.
\end{abstract}

Keywords-Hussain sagar lake, Oxygen uptake, Self purification capacity, organic pollutants.

\section{INTRODUCTION}

Lakes are one of the surface water sources for the human needs, and they are most useful for developmental activities in and around the areas where they existed, they serve infiltration source for ground water, for recharge of water to the water table, in addition to these, lakes can receive domestic sewage and industrial effluents from the catchment area they existed and turn into disposal sites for waste water. In contrast to the perennial flowing water bodies like streams and rivers, mostly the natural lakes are formed at mountain areas, where as the artificial lakes are also constructed in and around the cities to meet the water demand of that particular area, and also to serve wastewater basins for the catchment area they existed. Lakes can retain the waste materials without disturbing ecosystem up to certain extent, but when the discharging wastewater loads increasing, they will lose the ability of self purification process. Due to rapid industrialization and population growth, the requirement of water being increased at alarming rate in order to meet the water requirements of future generation, there is great need of protecting water bodies to promote sustainable development ${ }^{[1]}$.

Many Rivers and natural water bodies across the world are being polluted by domestic and industrial sewage due to a wide range of pollutants. Some of the pollutants are persistent and stable environmental contaminants [2]. Domestic sewage poses health related issues while industrial effluents carry a wide variety of toxic elements like $\mathrm{Cd}, \mathrm{Cr}, \mathrm{Pb}, \mathrm{Hg}$ and $\mathrm{Zn}$ which can cause significant toxicity even in trace amounts. The pollutants enter various parts of environment by anthropogenic activities as well as natural processes and degrade the surface and ground water quality and make them unsuitable for drinking, industrial, irrigation, recreation or other purposes ${ }^{[3,4]}$.

Water bodies in flowing state normally have the capacities to purify itself from the contamination of external sources discharge into the river ${ }^{[5,6]}$. Self-purification of water is a tedious process involving physical, chemical and biological processes that occur simultaneously, allows lakes to restore its natural state over a certain period ${ }^{[7.8]}$.

The process of purification is mainly depends on absorption and dissolution of atmospheric oxygen from the water body surface. This absorbed and dissolved oxygen (DO) is necessary for the growth of bacteria to break down the organic and inorganic pollutants thereby reducing its strength for a period of time ${ }^{[9]}$. Self-purification capacity of water bodies is mainly depends on natural factors. These include the water velocity, depth, discharge and temperature 
[10]. The turbulent of water bodies helps the river to very clean because of the natural capacity to absorb and digest pollutants at a very high rate. Stagnant water bodies tend to become septic because of the low rate of oxygen absorption. Furthermore, the depth of the water body also affects the rate of diffusion and mixing of the absorbed oxygen ${ }^{[11]}$. The temperature of water is high; low DO concentration because biological and chemical activity increases ${ }^{[12]}$. At a certain temperature the saturated dissolved oxygen is the maximum DO level that a river can attain. Maximum DO ranges from $14.6 \mathrm{mg} / \mathrm{L}$ of $\mathrm{DO}$ at $0^{\circ} \mathrm{c}$ to $7.2 \mathrm{mg} / \mathrm{L}$ at $35^{\circ} \mathrm{c}{ }^{[13]}$.

\section{Hussain Sagar Lake :}

Hussain Sagar Lake was built in 1562 during the reign of the Qutb Shahi dynasty at Golkonda fort as shown in fig.1. It is an artificial lake built on a tributary of River Musi. The lake joins the cities of Hyderabad and Secunderabad besides adding an aesthetic appeal to the twin cities. The lake water was utilized for irrigation and drinking water needs from 1884 to 1930 . The total catchment area of the lake is $\underline{240}$ square kilometres (93 sq mi). Through four main feeder nalas named Picket Nala, Kukatpally Nala, Banjara Nala and Balkapur Nalla, wastewater from the catchment area reaches the lake. Till 1930s, the lake was the major source of water supply to the population of Hyderabad and later on it turns into wastewater basin as the lake has gradually started receiving sewage and industrial effluents through the feeder nallas. The Picket Nalla discharges mostly domestic sewage throughout the year into the lake from the northeastern side. Similarly the Banjara Nalla (from northwestern side) and Balkapur Nalla (from western side) discharge mostly domestic sewage into the lake. The Kukatpally Nalla was seen to be discharging a mix of domestic sewage and industrial effluents into the lake from the northern side. This practice of discharging municipal sewage, industry effluents and storm-water from over $\underline{240}$ square kilometres increased the content of organic matter, nitrogen and phosphorus. This suspended organic matter, rich in nutrients, caused eutrophication that allowed growth of algal blooms and water hyacinth ${ }^{[14]}$.

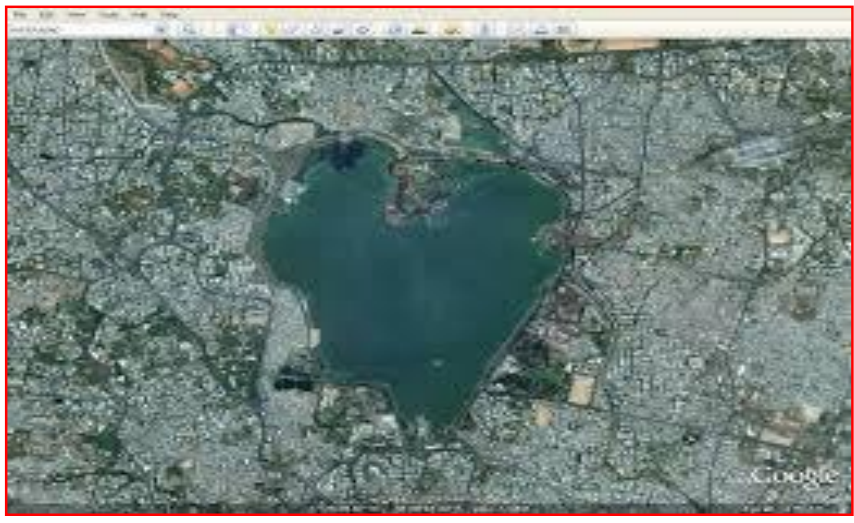

Fig.1: Satellite image of Hussain Sagar Lake

The lake is mainly fed largely by the Kukatpally nala, which contributes domestic and industrial effluents from the Kukatpally industrial area while other nalas discharges domestic sewage flows only as shown in Table 1 . Thus the water quality of the lake deteriorating due to the inflow of polluted water into the Hussain Sagar Lake.

Table.1: Inflows of domestic sewage and Industrial effluents

\begin{tabular}{|l|l|l|l|l|}
\hline Name of the Nala & $\begin{array}{l}\text { Domestic } \\
\text { flow, MLD }\end{array}$ & $\begin{array}{l}\text { Industrial } \\
\text { flow, MLD }\end{array}$ & $\begin{array}{l}\text { Total flow, } \\
\text { MLD }\end{array}$ & Remarks \\
\hline Kukatpally nala & 55 & 15 & 70 & Interception and diversion (I\&D) \\
\hline Picket nala & 6 & --- & 6 & $\begin{array}{l}\text { Interception and diversion after pumping, } \\
\text { Proposed STP (30 MLD capacity) }\end{array}$ \\
\hline Banjara nala & 6 & --- & 6 & Interception and diversion (I\&D) \\
\hline Balkapur nala & 13 & --- & 13 & STP (20 MLD capacity) \\
\hline Total & 80 & 15 & 95 & 50 MLD Treatment by Two STPs \\
\hline
\end{tabular}

\section{LITERATURE REVIEW}

The immersion of Ganesh idols in the lake every year has made it worse. It was reported that the water quality of Hussainsagar Lake is deteriorated with many heavy metals concentration in elevated levels than the ICMR standards [15]. It has also been reported that the kukatpally nallah carries the major quantity of pollutants which was determined by the sediment analysis at kukatpally nalla being heavily polluted by potentially toxic elements (PETs) [16]. Besides adding silt, studies indicate that these immersions have increased the pollution levels in the lake. The sediment and pore water analysis has shown elevated concentration of $\mathrm{Cr} \& \mathrm{~Pb}$ indicating settlement of various pollutants at bottom of lake ${ }^{[17]}$. All lakes serve to recharge the water table. But because of heavy pollution of Hussain sagar Lake, many of pollutants get carried into underground 
water bodies. Though percolation filters many pollutants, open wells or bore wells receive certain pollutants causing ground water pollution. Elevated levels of certain chemicals like $\mathrm{Hg}, \mathrm{Cd}, \mathrm{Pb} \& \mathrm{Ni}$ have been reported around Hussain sagar lake ${ }^{[18]}$.

\section{Cleaning the Hussain Sagar lake programme:}

To address the lake water quality, Hyderabad Metropolitan Development Authority (HMDA) has made efforts to restore a highly polluted Hussain sagar Lake to its pristine glory. The project entitled "Hussainsagar Lake and catchment area improvement project" which initiated in March 2006, aims at improving lake water quality by preventing entry of pollutants into lake from both point and non-point sources of pollution, besides removal of nutrient rich sediment. Interception and diversion of dry weather flows, improvement of nallas in catchment area ${ }^{[14]}$.

As part of the project, seven fountains were installed in the lake in September 2011 to improve the dissolved oxygen content in the water and help aquatic life as well as to add the beauty to the lake. Additionally, a new 30 MLD sewage treatment plant (STP) on the Picket nalla and 20 MLD STP adjacent to Khairatabad Flyover at Balkapur nalla, construction of ring sewers around the lake and a small treatment plant of 5 MLD at Rangadhamini chervu were as a part of project implementation. Dredging and disposal of sediment was also planned for this project. It was said that dredging from Picket nalla, Balkapur nalla and Banjara nalla will result in extraction of 7 lakh cu.m of non hazardous and nutrient rich sediment. Similarly many more projects are running today with aim of cleaning the lake such as A Clean Hussain sagar campaign (launched in 2013) and Canadian technology to rejuvenate Hussain sagar lake (March 2017).

Many projects are undertaken for the improvement of Hussain sagar lake and its catchment area as shown in Table2.

Table.2: Interventions undertaken for Hussain sagar lake improvement

\begin{tabular}{|l|l|l|l|l|l|}
\hline S.No & Name of the project & Scheme & Budget, rupees & $\begin{array}{l}\text { Year } \\
\text { Sanctioned }\end{array}$ & Status \\
\hline 1. & $\begin{array}{l}\text { Abatement of pollution of } \\
\text { Hussain sagar lake project }\end{array}$ & MCH & 40 Crore & 1998 & Completed \\
\hline 2. & $\begin{array}{l}\text { Green Hyderabad } \\
\text { Environment Programme }\end{array}$ & HUDA & Not Available & 2002 & Completed \\
\hline 3. & $\begin{array}{l}\text { Musi River Action Plan lake and } \\
\text { Catchment area Improvement } \\
\text { Project }\end{array}$ & NRDA & 370 Crore & 2006 & Completed \\
\hline
\end{tabular}

\section{Need of the Study}

Hussain Sagar Lake built in 1562 by Hazrat Hussainshah Wali was the major water resource for the both hyderabad and secunderbad. Earlier up to 1930's it was used for the daily needs of people, later on due to rapid urbanization as well as industrialization it turns to sewage effluent tank with insufficient treatment due to heavy loads of pollutants. Hence the lake loses the capability of self purification system. In order to restore the capacity of self purification system of the lake as well as to promote sustainable development of Lake Ecosystem by stopping ground water contamination and managing water quality in rivers to its downstream, proper measures must be taken to bring down the pollutant loads to an acceptable range in the lake and also improvement of health status of the Lake.

\section{Objectives of the study}

- Examining health status of Hussain Sagar Lake from past to present

- Examining of Self purification capacity of the Lake

\section{MATERIALS AND METHODOLOGY:} Study site:

It is estimated that nearly 350 MLD (Million Liters/ Day) of polluted water and sewage originating from the twin cities of Hyderabad and Secunderabad flow into the Musi river ${ }^{[19]}$. Out of 350 MLD, 95 - 120 MLD sewage was recieving to the lake after it was treated with the treatment plants $(20$ MLD STP and 30 MLD STP) which were set up upstream of lake and a very little quantity of sewage with no treatment ${ }^{[20]}$.

Over a decade, Hussain sagar lake receiving huge amount of waste water through four major inflow nallahs, namely, Picket, Balkapur and Banjara channels are located at north, 
south and southwest directions of lake and receiving about 30, 17 and 15 million liters per day (MLD) of treated and untreated wastewater respectively. Kukatpally nallah located at northwest direction of the lake having four industrial estates and receiving 60 to 70 MLD of domestic $\&$ industrial effluents, and all these four stations are inflow sites to the lake ${ }^{[21]}$. Numerous efforts to clean it have failed. The Lake water is highly polluted while huge wastewater loads recieving. Therefore the water health status is necessory to make the Hussain Sagar Lake clean. The salient features of Hussain Sagar Lake are presented in the below given Table 3.

Table.3: Features of Hussain Sagar Lake

\begin{tabular}{|l|l|}
\hline Item & Description \\
\hline Inlets & $\begin{array}{l}4 \text { Major nalas, namely, Banjara Nala, Picket Nala, } \\
\text { Kukatpally Nala and Balkapur Nala }\end{array}$ \\
\hline Outlets & 2 surplus weirs \& 4 sluice gates \\
\hline Max. Depth & $32 \mathrm{ft}$. \\
\hline Water Spread Area & 4.7 square kms \\
\hline Total Catchment Area & $240 \mathrm{~km}$ \\
\hline Direct Catchment Area & $67 \mathrm{~km}$ \\
\hline Capacity & $23.5 \mathrm{million}$ cubic meters \\
\hline Circumference & $14 \mathrm{~km}$ \\
\hline Surface Elevation & $1,759 \mathrm{ft}$ \\
\hline
\end{tabular}

Methodology:

Water samples were sampled from different locations in the lake at different seasons and transferred into pre cleaned polythene containers for analysis of pollutants using the standard procedures recommended by APHA ${ }^{[22]}$. Pollution indicator parameters like dissolved oxygen (DO), BOD, COD, total nitrogen and phosphates are considered for the study of reviewing the water quality status of the Hussain Sagar lake, Hyderabad.
The adopted methodology for this study is to assess the health condition of the lake with respect to the level of pollutant concentrations prevailing in it.

- Reviewing the treatment plants based on the quantity of wastewater load.

- Reviewing scientific approaches to restore self purification system of the lake.

- Recommendations to promote sustainable development by protecting aquatic ecosystem at study area.

\section{RESULTS AND DISCUSSIONS}

Previous studies on Hussain sagar lake:

Table.4: VISION LABS REPORT, 27.03.2017

\begin{tabular}{|l|l|l|l|l|}
\hline \multirow{2}{*}{ Parameters } & \multicolumn{3}{|c|}{ Hussain sagar lake sampling point } & BIS $\begin{array}{r}\text { (2012) } \\
\text { STANDARDS }\end{array}$ \\
\cline { 2 - 5 } & Budda sattue & $\begin{array}{l}\text { Lake outlet at boats } \\
\text { club }\end{array}$ & $\begin{array}{l}\text { Lake at Necklace } \\
\text { road }\end{array}$ & 7.28 \\
\hline $\mathrm{pH}$ & 7.2 & 7.3 & 39.7 & $6.5-8.5$ \\
\hline Turbidity & 31.6 & 27.1 & 1582 & 1500 \\
\hline $\mathrm{EC}$ & 1616.70 & 1506 & 489 & 200 \\
\hline T.Akalinity & 467 & 508 & 866 & 500 \\
\hline TDS & 848 & 852 & 216 & 100 \\
\hline $\mathrm{TSS}$ & 36.9 & 219 & 117.2 & 250 \\
\hline $\mathrm{Cl}^{-}$ & 118.4 & 116.6 & & 200 \\
\hline $\mathrm{SO}_{4}{ }^{--}$ & & & 13.84 & 45 \\
\hline $\mathrm{NO}_{3}{ }^{-}$ & 14.16 & 12.76 & 29 & 10 \\
\hline T.Nitrogen & 28.6 & 27.6 & 3.96 & 5 \\
\hline Phosphorous & 4.2 & 3.94 & 4.4 & 4 \\
\hline DO & 3.4 & 3.9 & & \\
\hline
\end{tabular}




\begin{tabular}{|l|l|l|l|l|}
\hline BOD & 41.8 & 50.2 & 53.4 & 30 \\
\hline COD & 122.8 & 153.2 & 146.8 & 250 \\
\hline
\end{tabular}

It was noted from the Table 4 that the values of BOD were observed at high concentration which indicates the presence of considerable pollution in the lake waters, Chlorides of water samples were observed ranging from 108-126 mg/l, Dissolved oxygen was observed in the range of 1.7-21.8 $\mathrm{mg} / \mathrm{l}$, Ammonical nitrogen was existed in the range of $4-$ $29 \mathrm{mg} / \mathrm{l}$, Nitrates were in the range of $10-24 \mathrm{mg} / \mathrm{l}$ and total phosphates were in the range of $2.8-9.2 \mathrm{mg} / \mathrm{l}$, due to this there is no big evidence of eutrophication. Total suspended solids was existed in the range of $146-278 \mathrm{mg} / \mathrm{l}$ at the outset even though the lake was fully contaminated the consistency in the pollutant concentration remains same as there is no big differentiation of physico chemical analysis of lake water during the three months period of analysis due to the less inflow of water as the rain fall intensity during study period is minimum ${ }^{[23]}$.

Table.5: Status of Hussain Sagar lake pollution

\begin{tabular}{|l|l|l|l|l|l|l|l|l|}
\hline Parameters & $\begin{array}{l}\text { NEERI } \\
(1996 \\
97,2000)\end{array}$ & $\begin{array}{l}\text { EPTRI } \\
(2015)\end{array}$ & 2008 & 2010 & 2014 & 2016 & 2017 & $\begin{array}{l}\text { LIMITING } \\
\text { STANDARDS }\end{array}$ \\
\hline $\mathrm{pH}$ & - & - & 9.2 & $\begin{array}{l}6.5- \\
8.5\end{array}$ & 8 & $8.1-9$ & 7.2 & $6.5-8.5$ \\
\hline TDS & $700-1100$ & $\begin{array}{l}940- \\
1200\end{array}$ & - & 900 & 761.3 & 1126 & 848 & 500 \\
\hline TSS & - & - & 52 & - & - & - & 36.9 & 100 \\
\hline Phosphates & $1.5-5$ & $0.4-1.5$ & - & - & - & - & 4.2 & 5 \\
\hline Total Nitrogen & - & - & - & - & - & - & 28.6 & 10 \\
\hline DO & - & - & 2.3 & 0 & - & 3 & 3.4 & 4 \\
\hline BOD & $20-48$ & $42-80$ & 55 & 20 & - & 25 & 41.8 & 30 \\
\hline COD & $76-203$ & $110-183$ & 140 & 170 & 115.5 & 289 & 122.8 & 250 \\
\hline
\end{tabular}

Note : All parameters have a unit of $\mathrm{mg} / \mathrm{l}$, except $\mathrm{pH}$.

- Indicates no data available.

It was observed from Table 5 that different studies over years carried out by many researchers that the value of Total Dissolved Solids (TDS) holds high concentration levels, which indicates the presence of considerable pollution in the lake, while Total suspended solids concentration levels varies from 36.9 -58 mg/l were considered within the desirable limits.

The DO was observed very low value varies from 0 to 3.4 $\mathrm{mg} / \mathrm{L}$ indicating fragile water quality, and the BOD was moderately high concentrations varies from $20-48 \mathrm{mg} / \mathrm{l}$ indicating organic pollution, the COD values are medium varies from 76 to $289 \mathrm{mg} / \mathrm{L}$ and are considered within the desirable limit. The data clearly indicates the occurrence of sewage pollution due to the convergence of untreated domestic sewage and solid waste containing oxidizable organic matter into the lake water ${ }^{[25]}$. The data indicates that the lake water was moderately alkaline and the $\mathrm{pH}$ values of $6.5-9.2$ were within the permissible limits. Phosphates representing eutrophication were within in the desirable, while Total nitrogen value of $28.6 \mathrm{mg} / \mathrm{l}$ was representing eutrophication conditions in the lake. The deterioration of lake water quality could be linked to nutrient loading from domestic sewage. The raw sewage is the source of nitrates and phosphates in the water ${ }^{[26]}$.

\section{CONCLUSIONS}

Hussain sagar is a 450 -year-old water body. Every day, 78 million litres of sewage and 15 million litres of industrial effluents flow into the lake through four drains. Of these, a major quanity of sewage has been treating through two STP's, while less quanity was being untreated. However the two sewage treatment plants (STPs) near the lake are insufficient to handle the wastewater load. It has reportedly found that the lake has lost its natural ability to 'self-purify' itself due to heavy load of contaminants as dissolved oxygen levels reaching the lowest and the worst pollution in lake is due to organic and inorganic substances that have seeped into the lake bed, and turned it to virtual garbage 
bin. The Hussain Sagar Lake suffered continuously for decades from the sewage flowing from four nalas being dumped into it and the fear has been that one day the lake will end up as a large sewage effluent tank in the heart of Hyderabad if suitable measures have not taken up.

HMDA had made efforts to restore Hussain Sagar Lake to its past glory in all respects by appropriate technological interventions. In 2006, HMDA initiated Hussain sagar Lake and Catchment Area Improvement project and set up STPs and wastewater interception and diversion structures. It also installed fountains to aerate the lake to improve its water quality. But all these measures have been ineffective.

It was concluded that the rejuvenation and conservation of Hussain Sagar lake is utmost interest of Hyderabad city as its ecological, cultural and touristic value is immense. One of the most important steps in the rejuvenation and conservation of the lake is to restore the water quality by controlling the pollution through different remedial measures.

To restore Self purification capacity of Hussain Sagar lake, following are the alternative to be taken up, which may give best results.

- By upgrading and installing STP's at inlets

- Installing aerating devices

- Preventing Discharge of untreated domestic sewage and industrial effluents,

- Evacuate Immersed of ganesh idols contributing to the high pollution and

- Shoreline monitoring of lake acts non point source of pollution

\section{DECLARATION OF CONFLICT OF INTEREST:}

The Author declares that there is no conflict of interest.

\section{REFERENCES}

[1] M. Satish Kumar, M.V. Raju, Hepsibah Palivela and G. Venu Ratna Kumari, Water Quality Scenario of Urban Polluted Lakes - A Model Study. International Journal of Civil Engineering and Technology, 8(5), 2017, pp. 297-302.

[2] Karadede-Akin, H. and Unlu, E., "Heavy metal concentrations in water, sediment, fish and some benthic organisms from Tigris River, Turkey". Environmental Monitoring and Assessment, 131: 323337, 2007.

[3] Carpenter, S. R., Caraco, N. F., Correll, D. L., Howarth, R. W., Sharpley, A. N., \& Smith, V.H., "Nonpointpollution of surface waters with phosphorus and nitrogen" Ecological Applications, 8, 559- 568. 1998.

[4] Howarth, R. W., Billen, G., Swaney, D., Townsend, A., Jaworski, N., Lajtha, Downing, A.,Elmgren, R.,Caracoa, N., Jordan, ., Berendse., F., Freney, J., kudeyarov, J., Kudeyarov, V., Murdoch, P., Zhu ZhaoLiang., Regional nitrogen budget and riverine $\mathrm{N} \& \mathrm{P}$ fluxes for the drainages to the North Atlantic Ocean: Natural and human influences". Biogeochemistry, 35, 75-139. 1996.

[5] Maamar Mokadem, Djillali Achour and Amine Cherif E.l. (2014). Study of self-purification capacity in semiarid zones: Case of wadicheliff, (Northern Algeria). Journal of current world Environment, 9(3), 584. http://dx.doi.org/ 10.12944/CWE.9.3.05.

[6] Omole D.O., Adewumi L.K., Longe E.O. and Ogbiye A.S. (2012). Study of auto purification capacity of river atuwara in Nigeria, International journal of engineering and technology, 6(3), 151-157, http://dx.doi.org/ 10.3923/erj. 2012.151.157.

[7] Kaushik Rajat (2015). Mathematical modelling on water pollution and self-purification of river Ganges. Journal of pelagia research library, 6(7), 57-64. http://docplayer.net/ 27705088.

[8] Menezes Paulo oao Cunha de, Bittencourt Parreira Ricardo, Farias Sá Matheus De, Bello Pinheiro Italoema, Oliveira Luiz Fernando Coutinho de and Fia Ronaldo (2015). Deoxygenation rate, reaeration and potential for self purification of small tropical urban streams. Revista Ambiente \& Água, 10(4), 748-757. http://dx.doi.org/ 10.4136/ambi-agua.1599.

[9] Schiewer Ulrich and Schernewski Gerald (2004). Selfpurification capacity and management of Baltic coastal ecosystems. Journal of coastal conservation., $10(1), \quad 25-32$. http://dx.doi.org/10.1652/14000350(2004)010 [0025:SCAMOB]2.0.CO;2

[10] Tian Shimin, Wang Zhaoyin and Shang Hongxia (2011). Study on the self-purification of Juma river. Journal of environmental sciences., 11, 1328-1333. http://dx.doi.org/ 10.1016/j.proenv.2011.12.199

[11] Madras school of Economics (MSE) (2005). Environmental issues in the Bhavani river basin unpublished interim report. Chennai MSE. http:// ageconsearch.umn.edu/ bitstream/91902/2/CA.

[12] Mehrdadi N., Ghobadi M., Nasrabadi T. and Hoveidi H. (2006). Evaluation of the quality and selfpurification potential of Tajanriver using QUAL2E model. 3(3), 199204. http://www.bioline.org.br/pdf?se06028. 
[13] Prati L. and Richardson Q.B. (1971). Water pollution and self-purification study on the PO river below ferrara. Water research, 5(5), 203-212. https://dx.doi.org/ 10.1016/00431354(71)90053-4.

[14] Jayesh Ranjan, Reddy, K. S. (2008). "Conservation of Hussain Sagar Lake Hyderabad (Andhra Pradesh, India)" (PDF). Proceedings of Taal 2007: The 12th World Lake Conference: $\underline{1753}-1756$.

[15] M. Vikram Reddy, K. SagarBabu, V. Balaram, M. Satyanarayanan., "Assessment of the effects of municipal sewage, immersed idols and boating on the heavy metal and other elemental pollution of surface water of the eutrophic Hussainsagar Lake, Hyderabad, India", Environmental Monitoring and Assessment. 184, 2012.

[16] V.V.S. Gurunadha Rao, Mitsuo Yoshida, B.A. Prakash, S.V.N. Chandrasekhar, and K. Mahesh Kumar, (November, 2004), "Environmental Impact of Human activities to Urban Lake Sediments:Potentially Toxic Elements (PTEs) Contamination in Hussainsagar Lake, Hyderabad". The 11th National Symposium on Hydrology, National Institute of Hydrology, Roorkee (India).

[17] S. Umamaheswara Reddy, Dr.P.Venugopal Rao., (2013) "Analysis of Sediment and Pore Watersamples of a Contaminated Lake - A Case Study of Hussain Sagar", International Journal of Emerging Technology and Advanced Engineering Volume 3, Issue 3, 841,.

[18] R. Srikanth, A. M. Rao, C. S. Kumar and A. Khanum, "Lead, Cadmium, Nickel, and ZincContamination ofGround Water around Hussain Sagar Lake, Hyderabad, India," Bulletin of Environmental Contamination and Toxicology, Vol. 50, No. 1, pp. 138-143, 1993.

[19]I. Bob Pears, C.V.V.Prasad, Dr. M. Chandra Sekhar, "Assessment of Water Quality Status of Musi River A Tributory of River Krishna in India," Int,. J. Environmental Science and Computing, Vol.6, No.11, pp. 3415-3422, 2016.

[20] Basmah Muner Mahmood, (October 2016) "Sewage Treatment Plant Of Hussain Sagar Lake, HyderabadA Case Study," Int. J. of Research, Vol.3, No.14, pp.515-534,.

[21] A. Sridhar kumar et.al., (Sep 2014) “Assessment of water quality in Hussain sagar lake and its inlet channels using multivariate statistical techniques," IJSER, Vol.5, No.9, pp.327-333,.
[22] APHA, AWWA, WEF. (1995) 'Standard Methods for Examination of water \& wastewater', 19th edition, APHA, AWWA, WEF, Washington, D.C.

[23] The Hindu, News Article -vision lab report, Hyderabad March, 2017,

[24] Bureau of Indian Standard (BIS), Indian standard Drinking water Specification (Second Revision), Indian Standard (10500:2012).

[25] Usharani.K. et al., (2010) "Physico-chemical and bacteriological characteristics of Noyyal river and ground water quality of perur, India. J. of Applies Sci. Environ. Management, 14(2), 29-35.

[26] Aggarwal T.R., Singh K.N, Guptha A.K, ( 2000) "Impact of sewage containing domestic water and heavy metals on the chemistry of Varuna river water", Pollution Research, 19(3), 491-494. 